Synthesis, part of a Special Feature on Exploring Social-Ecological Resilience through the Lens of the Social Sciences: Contributions, Critical Reflections, and Constructive Debate

\title{
Social-ecological systems, social diversity, and power: insights from anthropology and political ecology
}

\author{
Michael Fabinyi ${ }^{1}$, Louisa Evans ${ }^{2}$ and Simon J. Foale ${ }^{3}$
}

\begin{abstract}
A social-ecological system (SES) framework increasingly underpins the "resilience paradigm." As with all models, the SES comes with particular biases. We explore these key biases. We critically examine how the SES resilience literature has attempted to define and analyze the social arena. We argue that much SES literature defines people's interests and livelihoods as concerned primarily with the environment, and thereby underplays the role of other motivations and social institutions. We also highlight the SES resilience literature's focus on institutions and organized social units, which misses key aspects of social diversity and power. Our key premise is the importance of inter- and multi-disciplinary perspectives. To illustrate this, we draw attention to the critique of earlier ecological anthropology that remains relevant for current conceptualizations of SESs, focusing on the concepts of social diversity and power. And we discuss insights from social anthropology and political ecology that have responded to this critique to develop different ways of incorporating social diversity and power into human-environment relations. Finally, we discuss how these social science perspectives can help improve the understanding of the "social" in SES resilience research.
\end{abstract}

Key Words: anthropology; political ecology; power; social diversity; social-ecological system

\section{INTRODUCTION}

Underpinning current use of the "resilience paradigm" is a focus on the social-ecological system (SES). The SES is a model with the attendant biases and particular strengths and weaknesses that come with all models (anthropological, ecological, economic, and political). In particular, social elements of the SES remain weakly theorized, highlighting the need for a Special Issue such as this. We focus on how much SES resilience literature tends to define people's interests and livelihoods as concerned primarily with the environment. This underplays the role of other motivations and social institutions, and portrays a limited understanding of the importance of social diversity and power. We discuss insights from the social sciences - in particular, social anthropology and political ecology - to critique the concept of SES, with a focus on the concepts of human adaptation to the environment, social diversity, and power. Emphasizing the importance of interdisciplinary learning, we analyze how these social sciences have addressed similar conceptual issues within their own intellectual histories as a response to critiques of earlier forms of ecological anthropology. In our conclusion, we discuss to what extent this can contribute to a broader intellectual understanding of the "social" in SES resilience research.

As the SES model moves from a predominantly ecological base and audience to become a highly influential conceptual framework in broader academic and policy circles (MEA 2003, Béné et al. 2012), it is important to subject the assumptions and arguments the SES literature makes about social life to different disciplinary and epistemological perspectives. In recent years, there has been a growing recognition that the emphasis on human relations with the environment has led to a weak theorization of the "social" in the SES model. Social science scholars have attempted to address these conceptual limitations by proposing new versions of what the social should consist of (Bohle et al. 2009, Cote and Nightingale 2012, Armitage et al. 2012, Hatt
2013). Among the wealth of current commentary and discussion surrounding social aspects of the SES model, two prominent themes have been a broad emphasis on the complexity of social life and social processes (Armitage and Johnson 2006, Armitage 2008, Leach 2008, Crane 2010, Hatt 2013), and the role of power and values (Fabinyi 2009, Hornborg 2009, Coulthard 2012, Robards et al. 2011).

Our key premise is the importance of inter- and multidisciplinary perspectives. In many cases, debates within particular disciplines have already been discussed in similar ways in other fields. Current debates about social diversity and power in the SES resilience literature can be informed by how other disciplines and fields have attempted to address similar problems in the past. We focus on how the concepts of internal social differentiation (labeled here as social diversity) and power emerged in the fields of social anthropology and political ecology as a response to critiques of earlier ecological anthropology of the 1960s. We do not attempt to provide comprehensive or indepth accounts of how these concepts have been used, but focus on how particular threads within this literature have shifted from a view of the environment as the primary structural influence on people's behavior to a broader approach that takes into account social diversity and power. Similarly, we do not aim to use these ideas simply to critique the concept of the SES but to highlight their relevance for conceptualizations of the social in SES research, and to what extent they can be used.

We discuss current approaches to understanding the social in the SES literature, and review in greater detail the critique of limited attention to social diversity and power. We then focus on how these two concepts have been addressed in social anthropology and political ecology, and then discuss to what extent these sorts of perspectives can usefully be integrated with or compared with the SES perspective.

${ }^{1}$ Australian Research Council Centre of Excellence for Coral Reef Studies, James Cook University, ${ }^{2}$ Geography, College of Life and Environmental Sciences, University of Exeter, ${ }^{3}$ Department of Anthropology, Archaeology and Sociology, James Cook University 


\section{RESULTS}

Depicting the social in resilient social-ecological systems While the concept of resilience has foundations in many fields, including psychology, education, and health, it is primarily in the environmental sciences that the resilience of systems rather than individuals has come to the fore. Resilience describes a system property-so, a resilient system can absorb disturbance without undergoing structural and functional change. Resilience thinking or science refers to the many concepts used to describe processes of change that differ from mainstream thinking about "the balance of nature" and the linear relationship between exploitation and collapse (Scoones 1999, Walker et al. 2004, 2006, Abel et al. 2006, Folke 2006, Walker and Salt 2006). As Duit et al. (2010) articulate, resilience thinking is not a unitary concept. It is employed in multifaceted and diverse ways. Resilience scholars do not necessarily subscribe to all concepts within resilience science, nor do they suggest that change always occurs in a nonlinear, adaptive way. They do argue, however, that acknowledging that change can occur as described in resilience science has important implications for how we understand, interact with, and govern the environment. And in this endeavor, they almost always take a systems approach.

A focus on the resilience of SESs has gained considerable traction in the last decade. The idea of a tightly coupled SES emerged in parallel with resilience thinking (Berkes and Folke 1998). In an SES, feedbacks between social and ecological processes mean that any separation between the two is artificial. As articulated by Berkes and Folke (1998) in Linking Social and Ecological Systems, this systems approach emerged in opposition to mainstream utilitarian views in natural resource management and the commodification of nature. "The systems approach is replacing the view that resources can be treated as discrete entities in isolation from the rest of the ecosystem and the social system" (Berkes and Folke 1998:2). It emphasizes that humans are a part of nature, not external to and dominant over it. The SES framework is only one articulation of this alternative viewpoint. Dualist depictions of nature and culture had been critiqued in the social sciences arena many years earlier (Strathern 1980, Cronon 1995, Descola and Palsson 1996). But such views were not accepted in conventional ecology at the time (Berkes and Folke 1998).

As another perspective of relevance to natural resource management, resilience merged with ideas about the SES, and the two are now effectively synonymous (Gunderson and Holling 2002). As with any conceptual model, the SES resilience framework comes with attendant biases. While recent literature is more diverse (as we discuss at the end of the paper), we argue that such biases remain strong influences in much SES resilience thinking. We identify three main biases: (1) the tendency to assume that within an SES, people's knowledge, values, and livelihoods are concerned primarily with the environment; (2) the tendency to aggregate or homogenize social complexity and thereby assume that people's interests, expectations, and experiences are the same; and (3) the value-laden use of resilience within the social arena. These biases are manifest in the resilience literature in its corresponding emphasis on (1) simplified notions of human adaptation to the environment and the role of traditional ecological knowledge, (2) institutions and organized social units, and (3) positive attributes associated with resilient SES.

We look at each of these biases in turn before discussing how social anthropology and political ecology have historically addressed similar biases. To exemplify our three points, we provide examples from iconic resilience texts and papers. These publications are still very highly cited in the field, and thus, seemingly continue to provide the foundations of SES resilience research. Focusing on key literature helps with clarity but may simplify the diversity of scholarship now falling under the banner of resilience science. We reflect on some of the more diverse literature at the boundaries or frontiers of resilience science (depending on one's perspective) in our discussion.

\section{Human adaptation to the environment}

Globally, millions of people's livelihoods depend directly on the natural environment. Assumptions are often made that the institutions associated with these livelihoods evolve primarily as a means for humans to regulate their use of natural resources. This is prevalent within the SES literature. For instance, the body of research into traditional livelihoods typically describes the evolution of institutions and local adaptive management in terms of ecological knowledge and adaptation to environmental triggers. For instance, Berkes and Folke (1998:17) state, "Useful management lessons come from societies that have survived resource scarcities. These are societies that adapt to changes and learn to interpret signals from the resource stock through a dynamic social-ecological process, thus developing flexible institutions to deal with resource management crises." This statement is not incorrect but is arguably a narrow interpretation of institutional change focused on the role of environmental influences. Such interpretations have colored the lens of much empirical work, contributing to, we argue, an incomplete understanding of institutional emergence and evolution.

The iconic works of Johannes (1978, 2002), Berkes (1999), and colleagues (Berkes et al. 2000) have informed much discussion in the SES resilience literature about the potential for traditional knowledge to inform adaptive management and traditional institutions, such as taboo systems, to function as conservation tools (Castro and Nielson 2001, Olsson and Folke 2001, Drew 2005, Cinner and Aswani 2007, Davidson-Hunt and O'Flaherty 2007). Some of this literature acknowledges that these institutions were not necessarily designed for conservation purposes per se, but it still often portrays them as emergent primarily from environmental influences. There continues to be considerable interest in documenting local people's knowledge of environmental quality and change, on the assumption that this knowledge (or lack of) significantly influences people's norms and practices (Kittinger 2013). This perspective reflects the functionalist approach of early ecological anthropology (see Early ecological anthropology). Consequently, the socio-political and cultural origins of many local institutions are underplayed or overlooked. Other research has documented how many institutions emerge to maintain a particular socio-political status quo rather than to manage or conserve resources (Kremer 1994, Vedeld 2000, Neiland et al. 2005). For instance, research shows how the opening and closure regimes of traditional taboos are 
related primarily to cultural practices, such as death and feasting, or social needs, and are not typically informed by resource status or other environmental cues (Carrier 1987, Lieber 1994, Foale et al. 2011, Cohen and Foale 2013). For example, Glaesel (1997) suggests that many traditional practices linked to fisheries in East Africa are to appease spirits associated with health and safety at sea. And Chouin (2002) argues that sacred forests are sociopolitical artifacts used to maintain social order and manage conflict - they are revered because ancestors and leaders are buried there, not because of their natural attributes or importance in protecting biodiversity. Because of the potential secondary benefits of these cultural norms for resource management and biodiversity conservation, they are often reconstructed by scientists as community-based management institutions. "Greenwashing" these political, social, and cultural practices may obscure the impacts they have on different social groups, and misrepresent the reasons why they do or do not function effectively for secondary purposes such as environmental management.

\section{Emphasis on organized social units and institutions}

The SES resilience literature is increasingly informed by and intricately linked with the work of scholars such as Elinor Ostrom, Oran Young, and Francis Westley, who deal with the human dimensions of social and ecological dilemmas (Ostrom 1990, Young 2002, Westley et al. 2006). However, combining these perspectives with an SES approach means that the social is typically viewed in terms of organized social units, such as agencies, committees, and communities, and system structures, particularly institutions, rather than human agency and political and cultural relationships. For example, in putting forward a heuristic for analyses of SESs, Berkes and Folke (1998:17) explain that "the level of analysis is not the individual or the household but the social group, which could be a small community, a district, a tribal group or a regional population." The authors acknowledge that "even within the smaller, geographically bounded case-study areas, there will be considerable complexity in the user communities..." (Berkes and Folke 1998:17). Nevertheless, compared with the highly disaggregated social analyses found in political ecology and anthropology, the analytical lens recommended by resilience scholars emphasizes consensus and homogeneity over contestation and difference (Hatt 2013). According to Ostrom's (1990) institutional design principles, small group sizes and community homogeneity are desirable because they are associated with consensus, compliance, and more enduring rules. Similarly, for the purposes of developing institutional theory, the myriad of social differences in communities can be reduced to a few variables on "heterogeneity" (Wollenberg et al. 2007). As articulated by Brown (2014), recent perspectives on community resilience continue to underplay the dynamics of social difference. Bounding ecological knowledge or adaptive capacity to homogenous communities or social groupings neglects the different perspectives, beliefs, values, and experiences of people involved in and affected by resource management (Cote and Nightingale 2012). Social stratifications along the lines of gender, ethnicity, age, and so on are extremely important features of differences in how environmental change and management are administered and experienced by different people. The section Historical changes outlines how social science theory has highlighted and dealt with such cleavages.
Institutions have also featured predominantly in conceptualizations of the social in the SES resilience literature. This is indicated by the merging of the resilience and commons literatures (Berkes 2006, Cumming et al. 2006, Folke et al. 2007, Walker et al. 2009, Biggs et al. 2012), the burgeoning concept of adaptive comanagement (Olsson et al. 2004, Plummer and Armitage 2007), and the development of the SES framework for institutional analysis (Ostrom 2007). Institutions reflect social structures. As Coulthard (2012) notes, structural perspectives place emphasis on the external forces that direct people's behaviors. Overemphasis on institutions can create blind spots around issues of agency, which is unevenly distributed and largely about power (see Coulthard 2012 or Davidson 2010 for definitions). Power can be invested in institutions, but much mainstream institutional analysis tends to prioritize consensus and collective action over contestation. For example, much of Ostrom's (2005) work highlighted the importance of collective choice and constitutional institutions whereby people are involved in formulating and perpetuating (through monitoring and enforcement) the institutions that direct their own behavior. These concepts account for power and agency. However, where "resource users" (often understood as a coherent collective) are not involved in collective choice or constitutional institutions, the problem is expressed primarily in terms of lack of compliance and ineffective natural resource management rather than in terms of inequality, injustice, or detrimental impacts on people. Further, in some scholarship on institutions and SESs, institutions are portrayed as distinct from or outside of the social subsystem. Young (2010:379) argues that governance systems are as "complex and dynamic as the social-ecological systems they are created to steer." Is this not inevitable considering that the institutions, policies, and relationships that make up a governance system are part of the SES? Distinguishing institutions or governance systems from the SES suggests that governance systems can be rationally designed, independent of the messiness of people's interests and interactions. Scholars from more critical disciplinary backgrounds, such as Frances Cleaver, argue that the institutional and economic theories informing much of Ostrom's and other's work are apolitical, ahistorical, and highly normative (Cleaver 2000, Cleaver and Frank 2005). Ostrom (1998) herself wrote about the limitations of rational economic behavior models, referring instead to a bounded rationality. Her work does not assume a passive or rational relationship between people and institutions, but in its aim to uncover shared principles of institutional design (a notable, important, and necessary achievement), it does downplay local to global politics and the importance of cultural context and meaning (Agrawal 2005, Crane 2010).

\section{Power and the value-laden use of the term resilience}

Resilience as a system property is inherently value neutral. Both desirable and undesirable system states can be resilient to disturbance. This is represented by the concept of rigidity traps in resilience science (Scheffer and Westley 2007). However, resilience research still tends to associate positive attributes such as diversity, autonomy, connectivity, knowledge, and learning with resilient systems (Berkes and Seixas 2005). Folke et al. (2003, 2005) offer strategies for building SES resilience, including (1) learning to live with change and uncertainty, (2) nurturing diversity in its various forms, (3) combining different types of knowledge for learning, and (4) creating opportunities for self- 
organization and cross-scale links. These factors may well build resilience of desirable system configurations, but they are unlikely to be associated with resilient pathologies such as poverty and inequality. Note a recent assertion that "a resilient socialecological system fosters fairness, inclusivity and diversity, pluralism of knowledge, and social learning" (O'Brien et al. 2009:6). Little research has focused on the social factors that enhance the resilience of rigidity traps in SESs. This matters in SESs where the tension between exploitation and conservation of a system can mean very different outcomes for different people across spatial and temporal scales. What is desirable and for whom, how resilience is managed, and who decides are critical questions of power. Even the fundamental question of whether or not there is a "problem" or "crisis" to be managed is often contested (Forsyth 2003, Walker 2004, Cote and Nightingale 2012).

Crane (2010) argues that the resilience of ecological components of a system might be realized at the expense of social or cultural resilience of people whose beliefs and livelihoods are changed through management. Davidson (2010) points to the lack of diversity in the resilience of dominant development pathways such as the free-market system and dependence on fossil fuels (see also Shaxson 2011 for analysis of the long-enduring offshore tax system). And Coulthard (2012) highlights the potential for adaptation for enhanced resilience to significantly reduce people's well-being. Resilience scholars might counter that trade-offs between ecological and cultural resilience or adaptation and wellbeing are an artifact of the scale on which these issues are considered. An SES in which the loss of cultural values will, in the long term, undermine any benefits to ecological status is not a resilient system. Indeed, the nested systems perspective (panarchy) and, for example, the focus on fast and slow drivers require that scholars note relationships and trade-offs across spatial and temporal scales. For example, in her analysis of water management in South Africa, Erin Bohensky documents how a deep time perspective can capture the shifting societal values within which SESs are defined as more or less resilient (Bohensky and Lynam 2005, Bohensky 2008). In practice, even short-term trade-offs between system attributes and individual costs and benefits are meaningful to people and therefore must be acknowledged. As we argue in the Discussion and Conclusion, a focus on the societal winners and losers of resilient or transformed SESs could provide a much more politically sensitive approach to resilience science.

\section{Historical changes in conceptualizing social diversity and power in social anthropology and political ecology}

Criticisms of the SES model bear strong resemblances to similar criticisms of ecological anthropology of the 1960s. We introduce these historical debates and outline how the fields of anthropology and political ecology addressed some of these challenges related to social diversity and power.

\section{Early ecological anthropology}

Building on earlier work in anthropology, notably the "cultural ecology" approach developed by Julian Steward in the 1950s (Steward 1955), much ecological anthropology of the 1960s and early 1970s used a systems approach to understand the interactions between humans and their environments (Harris 1966, Rappaport 1968, Piddocke 1969, Vayda 1974, Lee and
Devore 1969). The most prominent example of this approach was Roy Rappaport's (1968) Pigs for the Ancestors, which analyzed the ritual practices of a Papua New Guinean highland society in terms of adaptation to the natural environment. Pigs were ritually slaughtered in a grand feast once their population became too high, allowing the pig-to-human ratio to be re-established and the environment to return to its natural carrying capacity. The use of biological concepts such as calories, ecological niche, energy, carrying capacity, and cybernetics became common.

This form of anthropology has been termed functionalism or neofunctionalism. As Orlove (1980:240) noted in an influential critique, "[t]he term neofunctionalism is used because the followers of this approach see the social organization and culture of specific populations as functional adaptations which permit the populations to exploit their environments successfully without exceeding their carrying capacity... [N]eofunctionalists explain specific aspects of social organization and culture in terms of the functions which they serve in adapting local populations to their environments." At the time, many criticisms were leveled at this approach (Friedman 1974, Orans 1975, Sahlins 1978). Broadly, the main charge was that of "ecological reductionism" - captured in Sahlins' (1978) description of this approach as solely concerned with "protein and profit." Ecological reductionism implied that the social organization and culture of these populations were determined by the environment, eliding discussions of other social processes and structures. This also had parallels with broader critiques of "structural functionalist" social anthropology at the time - anthropologists were beginning to acknowledge that the objects of their study were not pristine, isolated communities whose behavior was a function of their social structure but groups of people whose histories were shaped by capitalism, colonialism, and change (Leach 1954, Wolf 1982; see also Bell 2005 for an account of similar critiques leveled at Parsons' vision of functionalism in sociology). More recent critiques by anthropologists of Jared Diamond's (2005) “Collapse" have made similar points (McAnany and Yoffee 2010).

While the critique of "ecological reductionism" had many elements $^{[1]}$ (Orlove 1980), we focus on two specific weaknesses that emerged: a lack of attention to social diversity, and a lack of attention to power relations. Firstly, by choosing to focus on local populations as the unit of study - and indeed the unit of natural selection in an overtly evolutionary sense - the neofunctionalist approach neglected internal differentiation, ignoring the diversity of social groups within these local populations. Secondly, as the emerging field of political ecology was to highlight, there was a lack of attention to the broader social, economic, and political structures that these people were embedded in. By focusing on topics such as calories and energy in explaining human adaptation and the emergence of patterns of behavior and institutions, earlier ecological anthropology was neglecting how this behavior was often driven by markets and poverty.

Recent years have witnessed similar charges of functionalism and a lack of attention to social diversity and power in the resilience literature (Hornborg 2009, Hatt 2013). While clearly there are many examples in the SES literature that address social diversity and power relations within human populations in different ways (we discuss emerging examples of this literature in the conclusion), as a theoretical model, the SES model retains both 
of these limitations. By choosing to focus on people's relationship with their environment and how this environment shapes behavior, much work in resilience and SES science has the same theoretical limitations to that of earlier ecological anthropology. If the SES model is to provide theoretical and conceptual guidance for the perspectives and priorities of people, social diversity and power are two areas that will need to be explored in greater depth. The following section addresses the ways in which social anthropology and political ecology built on these critiques to address questions of social diversity and power.

\section{Social diversity: insights from social anthropology}

Developments in ecological anthropology since the late 1970s have included a focus on social diversity, in response to many of the critiques leveled at earlier ecological anthropology. As Orlove (1980:246) notes, this formed part of a broader shift in social anthropology "from social structure to social process, from treating populations as uniform to examining diversity and variability within them, and from normative and jural aspects to behavioral aspects of social relations." We focus on one example of this shift that has particular relevance for the SES model, which was a retheorization of the concept of community. Instead of viewing communities as spatially bounded, organized social units that tend towards harmony and consensus, the emphasis more recently has been to pay more attention to "the historical depth and spatial scale of the community" (Dove and Carpenter 2008:39). This has involved both a greater focus on linkages outside of what is typically considered to be the "community"for example, markets and trade - and social diversity within the community (Netting 1990, Brosius et al. 2005). One consequence of this has led anthropologists to emphasize hierarchies, conflicts, and tensions within communities. More common anthropological approaches to the environment now typically focus less on how a local population or community will behave in relation to the physical environment than on how different actors and interest groups within these communities interact with both their social and physical environment. This view resulted in a detailed anthropological critique of the ways that the concept of community has been used by conservation and development practitioners since the 1990s (Brosius et al. 2005).

A prominent example of how this shift in theorization of community took place in anthropology was in Melanesia, a region of the world where anthropology has long taken a particular interest. Rappaport (1968), Vayda (1974), and other neofunctionalists argued that community-scale groups can be sufficiently clearly bounded as to provide a plausible unit of selection where environmental limits are supposed to drive the evolution of adaptive social and cultural institutions. However, a review of much of the large body of Melanesianist anthropological work since the 1960s that has explicitly focused on systems of kinship and land tenure demonstrates key flaws in this assumption. In most Melanesian societies, land rights are claimed through systems of lineage-based descent reckoning as well as through residence and use. Residence-based use rights are often strengthened through time to become equal to descentbased rights. The cross-cutting nature of patterns of marriage and post-marital residence with rules of descent-reckoning have led to highly complex and flexible systems of land and marine tenure that allow for multiple and competing interpretations of rights to land and sea (Filer 1990, Foale and Macintyre 2000, Macintyre and Foale 2007). The complex fluidity of such systems has routinely produced deep political rifts within community groups in the context of the commodification of timber, minerals, and coastal fisheries in the post-colonial era, clearly demonstrating the profound lack of enduring political cohesion within these groups (Filer 1990, 1994, 1997, Otto 1997, Lattas 2011). This apparent lack of a social and cultural foundation for lasting political cohesion, sufficient for the collective innovation of "adaptive" institutions, poses a significant problem for neofunctionalist (and much SES) thinking in this cultural area.

More broadly, distinctions between people who are of different age, gender, class, and ethnicity, who belong to families with different status, and who have varying levels of interest in resource use are some of the more important cleavages within any community that frequently may be identified but for the purposes of broader analysis tend to be glossed over or simplified under the general categories of "local community" or "fisher/farmer" (Walker 2001, Eder 2005, Fabinyi et al. 2010). The specific implications of this shift in the view of the "community" for the SES model are that the social aspect of the SES is composed of contested and diverse human interests (Cleaver 2000, Armitage and Johnson 2006). People do not necessarily act together for the benefit of the community-instead, the social element of the SES contains a wide variety of contested interests. This may seem an obvious point, but it is one that is downplayed or elided by a systems model that focuses on how humans adapt to their environment, or assumes a level of homogeneity and common interests among human "populations." Any attempt to understand and address the social element of the SES in greater depth will need to find a more productive way of addressing the social diversity within communities.

In much recent social anthropology focusing on environment and development, the importance of the notion of diverse and contested interests has led to an increasing emphasis on the notion of trade-offs (Hirsch et al. 2011, Coulthard et al. 2011, McShane et al. 2011, Coulthard 2012). There has been increasing recognition in the environmental academic and policy community that "win-win" outcomes are in many cases impossible to achieve, and so the goal of much governance should be how to address and negotiate between competing goals and perspectives of different stakeholders. As Coulthard et al. (2011:460) note, "all conservation policy changes entail trade-offs between the wellbeing interests of different groups and individuals that are dependent on fisheries ecosystems." Discussions of trade-offs have recently been incorporated into the SES literature (Robards et al. 2011). While identifying and understanding different perspectives that need to be traded off is a good start, this is only the start of the process. The trade-off process inevitably involves power relations and contestation, which leads into the next section of how the field of political ecology has dealt with this issue.

Power: insights from political ecology

The interdisciplinary field of political ecology has a wide range of intellectual origins, but one important one was to build on the critique of earlier ecological anthropology about a lack of attention to power relations (Peet and Watts 2002, Robbins 2004). We distinguish two broad forms of political ecology (Brosius 1999a:303): the first drawing primarily on insights from political economy; the second drawing on poststructural social theory. 
The response to critiques of ecological anthropology drawing on political economy incorporated a wide range of neo-Marxian influences (Shanin 1971, Wallerstein 1974, Frank 1975), which argued that relations of resource users with the environment were mediated by market and capitalist relations. Early works in political ecology highlighted how environmental behavior was typically not driven by reasons directly related to the environment but by poverty and marginalization driven by political-economic forces at higher scales (Blaikie 1985, Blaikie and Brookfield 1987). While SES resilience literature has to some extent engaged with these fundamental ideas of political ecology (Peterson 2000), there has been less engagement with more recent versions of political ecology that use a wider range of theoretical approaches. This reflects the inherent fragmentary nature of the field, as the diversity of approaches that has been labeled as "political ecology" makes it difficult to define it as such (Brosius 1999a:303). One important influence on more recent forms of political ecology is Foucault's $(1972,1980)$ poststructural insights on power, knowledge, and discourse. More recent political ecology is characterized by the analysis of both material and discursive contestation, arguing that practical struggles are always simultaneously struggles for "truth" and meaning — struggles that happen in imagination and representation at the same time as they are conducted in the material world (Peet and Watts 2002:37). Drawing heavily on the work of Foucault $(1972,1980)$, it highlights the ways in which representations, narratives, and discourses shape how people perceive and behave in relation to the environment (see Brosius 1997, $1999 a, b$, Agrawal 2005, Tsing 2005, and $\mathrm{Li} 2007$ for examples of influential works that emphasize the ways in which power and knowledge matter for human-environment relations).

Brosius' $(1999 b, 2006)$ work on environmentalist campaigns among the Penan in Sarawak, Malaysia, highlights the importance of these discursive characteristics. He shows how the romantic and essentialized images of the Penan presented by environmentalists distorted and dehumanized them, reducing the complex situation of the Penan to simplistic narratives that were then used to advance the strategic objectives of environmentalists. Similarly, with regard to traditional ecological knowledge, Brosius has argued that this local knowledge and the way it is expressed should be regarded as a form of political knowledge, not just knowledge about the environment. His work demonstrates how local knowledge is typically expressed by local people who are concerned primarily with political problems of environmental rights and access. In direct contrast to the view that local environmental knowledge is concerned primarily with or related to environmental management, Brosius (2006:136) contends therefore that " $[\mathrm{w}]$ hat matters is not how much Penan know about the landscape they inhabit, but how they position that knowledge, and themselves, within the broader contours of power" (see also Filer 2009). More recent approaches in political ecology have explored how governance initiatives for the environment serve to change the ways in which subjects of these initiatives perceive and behave towards the environment, producing different thoughts and actions (Agrawal 2005, Dressler 2013).

The wider, fundamental point that is made in much of this literature is that the ways in which an environment (or an SES) is managed is not something that can be reduced to a matter of objective analysis. It is a value-laden exercise that is contested by groups with differential power, who employ a range of strategies that include debating and negotiating the very ways in which environmental issues are commonly understood and represented. From this critical discursive perspective, therefore, the SES resilience model could potentially be viewed as a perspective that brings into focus certain interests (the system as a whole, human relationships with the environment, the intrinsic value of that environment), while marginalizing others (social processes at a fine scale, human interests outside of or opposed to the environment). As Cote and Nightingale (2012:482) point out, " $[\mathrm{t}]$ he goal in conventional resilience research seems to be to get the facts right so they can be inserted into a (modeled) system. On the other hand, situating resilience problem formulations in contestations over knowledge brings to the fore questions about whose resilience we are concerned with, and to what end." Investigating how knowledge about the environment is produced is inevitably central to understanding how environmental problems, processes, and solutions are framed, normalized, and contested.

\section{DISCUSSION AND CONCLUSION}

As many otherwise critical social scientists have noted, the SES model represents a significant attempt to cross disciplines and build a holistic perspective on human-environment relations. Key limitations of this perspective, however, bear remarkable similarities to the limitations of earlier forms of ecological anthropology. We have focused on three specific elements that relate to such a perspective: an excessive focus on how humans adapt to their environments, a lack of attention to social diversity, and a lack of attention to values and power. We have examined how different strands of social anthropology and political ecology have responded to address these limitations. We now discuss the potential value of these perspectives to resilience science, and emerging examples in resilience literature that complement these perspectives.

In many ways, this paper, and many of the discussions in this Special Issue, more broadly, reflect the challenges involved in trying to integrate different forms of natural and social science. Different intellectual traditions often have fundamentally different assumptions and epistemologies, which can lead to basic misunderstandings among scholars about the nature of knowledge (Flyvbjerg 2001). For example, the goal of much positivist natural science is to progressively generate cumulative knowledge that can produce objective, generalizable information, or in Cote and Nightingale's (2012) words with reference to much SES resilience literature, "get the facts right." By contrast, more interpretive traditions in social science have typically held a strong skepticism of "grand narratives" that attempt to explain reality as if it were distinct from how humans perceive, measure, and interact with it.

Given these challenges, there are difficulties when attempting to present one view of how the "social" can be better conceptualized in an improved "model" of an SES. As Bell (2005) notes in a critique of the systems metaphor, there are significant problems in the idea of searching for a "theory of everything," and learning how to accept differences in disciplinary perspective is a fundamental part of meaning and learning. We suggest that instead of trying to explicitly integrate forms of social theory into 
an overarching "grand narrative" that describes the nature of reality, it may be more productive to adopt a more humble goal of simply fostering more genuine interdisciplinary dialogue. While this process is messier than the creation of neat conceptual models and frameworks, such interdisciplinary dialogue where divergent views and perspectives are explicitly borne in mind may in the long run prove more pragmatic and realistic. Although the critiques of ecological anthropology we have discussed are well established, SES resilience scholars have yet to reflect on them explicitly in several decades of research. Simply raising them again, explicitly, can help resilience scholars to understand that in conceptualizing the social, they do not need to "reinvent the wheel" but would do better to explore the evolution of other disciplines. We have suggested at least two entry points where the adoption of interdisciplinary dialogue may be of value to resilience studies - the importance of recognizing trade-offs, and a more critical understanding of how power operates.

To date, recognition of the importance of diverse and contested interests within an SES has received relatively little attention, but this has been changing in recent years with contributions from scholars from development studies (Béné et al. 2012, Coulthard 2012) and anthropology (Armitage and Johnson 2006, Fabinyi 2009, Leach 2008), and within resilience studies themselves (Duit et al. 2010, Robards et al. 2011). This focus on trade-offs among diverse and contested interests in SESs complements the work of other scholars in anthropology, environment, and development (Hirsch et al. 2011, McShane et al. 2011), who have emphasized the necessity of making the trade-offs in environmental decision-making as transparent and visible as possible. By increasing the focus on social diversity within an SES, resilience studies would be better able to understand how current or changed system configurations affect different people in different ways. This is essential in order to understand resilience at different spatial (e.g., individual, household, community) and temporal scales (historical, present, intergenerational).

We have also highlighted the need for a more critical understanding of power. While understanding the diverse perspectives of different interest groups in an SES is important, power relations mean that these different voices can be marginalized or privileged, easy to identify or invisible (Brosius $1999 b$ ). Importantly, power is not just focused on the material dimension but the discursive as well. A better understanding of the discursive dimensions of power in SESs would encourage resilience scientists to deconstruct whose voices become privileged and whose voices are silenced, and why, in debates over resilient SESs. Such deconstruction does not have to descend into extreme forms of postmodernist philosophical debate in order to be a powerful corrective to technocratic viewpoints that elide the existence of inequality (Ferguson 1994, Li 2007, Easterly 2014, Fabinyi et al. 2014). Despite some progress by resilience scholars in this direction, we argue that there remains much room for a greater engagement with these issues, and to make greater use of the approaches that help us understand them.

There are four ways in which trade-offs and power can be better incorporated into resilience science. First, and perhaps most importantly, our discussion has highlighted how the way we frame research questions and define the unit of analysis determines the sorts of questions asked and answered. Simply, a more explicit focus on different points of view, conflict, contestation, micropower dynamics (intracommunity and intrahousehold), and macrosystems dynamics (dominant political and economic systems) could significantly alter the contributions of resilience science to key societal challenges with environmental dimensions (poverty, inequity, security). By being more aware of such perspectives, we suggest that resilience scientists have the capacity to create more inclusive analyses that encompass a greater diversity of perspectives. Bohle et al. (2009) demonstrates clearly how the resilience of the urban food system in Dhaka was maintained at the expense of access to affordable food for the most vulnerable individuals in the SES. This was achieved through an explicit analytical focus on trade-offs across scales. Second, integration of conceptual and analytical ideas can offer new and practical tools for analysis. Resilience science is increasingly informed by scholarship on vulnerability (Nelson et al. 2007, Béné et al. 2012), climate change (Tompkins and Adger 2004, Adger et al. 2011), social innovation (Westley et al. 2011), governance (Duit et al. 2010), and development studies (Armitage et al. 2012, Marshall et al. 2012). More specifically, scholars have also attempted to integrate concepts such as the adaptive cycle and structuration theory (Pelling and Manuel-Navarette 2011), the adaptive cycle and entrepreneurship (Westley et al. 2013), and social and ecological attractors (Hatt 2013), to name a few examples. Third, methodologically, utilizing approaches that allow people to reflect on "the meaning of things" or their own interpretations of their and other's resilience, knowledge, adaptive capacity, and agency can add a new, little-explored dimension to resilience science (see Duit et al. 2010 for further reflections on conceptual and methodological choices in SES research). This could, for example, involve a greater engagement with ethnographic and other qualitative research methods (Fabinyi et al. 2010, 2014). Finally, conscientiously steering away from the normative bias often associated with resilience thinking, and focusing on the practical application and empirical outcomes of resilience in practice (whether good or bad overall and for specific societies, groups, and individuals) could inform a more grounded understanding of SES resilience. The uptake of resilience concepts in policy and practice that challenge the status quo (Brown 2014) provide a rich context for more politically sensitive analyses of resilience and social change.

In sum, we have highlighted the importance of understanding how other disciplines and fields have approached similar conceptual challenges to those that currently preoccupy many SES resilience scholars. We have focused on how social anthropology and political ecology have historically addressed challenges related to earlier ecological anthropological conceputalizations of social diversity and power. We specifically identified conceptual discussions surrounding trade-offs, and a scholarly tradition focusing on the intersections between power, knowledge, and contestation as important areas of contemporary research. By engaging with these areas of research, SES resilience scholars may be able to incorporate their insights into more grounded and pragmatic approaches to environment and development. 
Responses to this article can be read online at: http://www.ecologyandsociety.org/issues/responses. $\mathrm{php/7029}$

\section{Acknowledgments:}

This research was supported by the Australian Research Council Centre of Excellence for Coral Reef Studies, and a Branco Weiss - Society in Science Fellowship (M. Fabinyi).

\section{LITERATURE CITED}

Abel, N., D. H. M. Cumming, and J. M. Anderies. 2006. Collapse and reorganization in social-ecological systems: questions, some ideas, and policy implications. Ecology and Society 11(1):17. [online] URL: http://www.ecologyandsociety.org/vol11/iss1/ $\underline{\operatorname{art} 171}$

Adger, W. N., K. Brown, D. R. Nelson, F. Berkes, H. Eakin, C. Folke, K. Galvin, L. Gunderson, M. Goulden, K. O'Brien, J. Ruitenbeek, and E. L. Tompkins. 2011. Resilience implications of policy responses to climate change. Wiley Interdisciplinary Reviews: Climate Change 2(5):757-766. http://dx.doi.org/10.1002/ $\underline{\text { wcc. } 133}$

Agrawal, A. 2005. Environmentality: technologies of government and the making of subjects. Duke University Press, Durham, North Carolina, USA.

Armitage, D. 2008. Governance and the commons in a multi-level world. International Journal of the Commons 2(1):7-32.

Armitage, D., C. Béné, A. T. Charles, D. Johnson, and E. H. Allison. 2012. The interplay of well-being and resilience in applying a social-ecological perspective. Ecology and Society 17 (4):15. http://dx.doi.org/10.5751/ES-04940-170415

Armitage, D., and D. Johnson. 2006. Can resilience be reconciled with globalization and the increasingly complex conditions of resource degradation in Asian coastal regions? Ecology and Society 11(1):2. [online] URL: http://www.ecologyandsociety. org/vol11/iss1/art2/

Bell, M. M. 2005. The vitality of difference: systems theory, the environment, and the ghost of Parsons. Society \& Natural Resources 18(5):471-478. http://dx.doi.org/10.1080/08941920590924963

Béné, C., R. G. Wood, A. Newsham, and M. Davies. 2012. Resilience: new utopia or new tyranny? Reflections about the potentials and limits of the concept of resilience in relation to vulnerability reduction programmes. IDS Working Paper Number 405, CSP Working Paper Number 6.

Berkes, F. 1999. Sacred ecology: traditional ecological knowledge and management systems. Taylor \& Francis, Philadelphia, Pennsylvania, USA and London, UK.

Berkes, F. 2006. From community-based resource management to complex systems. Ecology and Society 11(1):45. [online] URL: http://www.ecologyandsociety.org/vol11/iss1/art45/

Berkes, F., J. Colding, and C. Folke. 2000. Rediscovery of traditional ecological knowledge as adaptive management. Ecological Applications 10:1251-1262. http://dx.doi.org/10.1890/1051-0761 (2000)010[1251:ROTEKA]2.0.CO;2
Berkes, F., and C. Folke. 1998. Linking social and ecological systems: management practices and social mechanisms for building resilience. Cambridge University Press, Cambridge, UK.

Berkes, F., and C. S. Seixas. 2005. Building resilience in lagoon social-ecological systems: a local-level perspective. Ecosystems 8:967-974.

Biggs, R., M. Schlüter, D. Biggs, E. L. Bohensky, S. BurnSilver, G. Cundill, V. Dakos, T. M. Daw, L. S. Evans, K. Kotschy, A. M. Leitch, C. Meek, A. Quinlan, C. Raudsepp-Hearne, M. D. Robards, M. L. Schoon, L. Schultz, and P. C. West. 2012. Towards principles for enhancing the resilience of ecosystem services. Annual Review of Environment and Resources 37:421-448. http:// dx.doi.org/10.1146/annurev-environ-051211-123836

Blaikie, P. 1985. The political economy of soil erosion in developing countries. Longman, London, UK.

Blaikie, P., and H. Brookfield. 1987. Land Degradation and Society. Methuen, London, UK.

Bohensky, E. L. 2008. Discovering resilient pathways for South African water management: two frameworks for a vision. Ecology and Society 13(1):19. [online] URL: http://www.ecologyandsociety. org/vol13/iss1/art19/

Bohensky, E., and T. Lynam. 2005. Evaluating responses in complex adaptive systems: insights on water management from the Southern African Millennium Ecosystem Assessment (SAfMA). Ecology and Society 10(1):11. [online] URL: http:// www.ecologyandsociety.org/vol10/iss1/art11/

Bohle, H. G., B. Etzold, and M. Keck. 2009. Resilience as agency. Update 2, International Human Dimensions Programme on Global Environmental Change.

Brosius, J. P. 1997. Endangered forest, endangered people: environmentalist representations of indigenous knowledge. Human Ecology 25(1):47-69. http://dx.doi.org/10.1023/A:1021983819369

Brosius, J. P. 1999a. Analyses and interventions: anthropological engagements with environmentalism. Current Anthropology 40:277-309. http://dx.doi.org/10.2307/2991397

Brosius, J. P. 1999b. Green dots, pink hearts: displacing politics from the Malaysian rain forest. American Anthropologist 101:3657. http://dx.doi.org/10.1525/aa.1999.101.1.36

Brosius, J. P. 2006. 'What counts as local knowledge in global environmental assessments and conventions?' In W. V. Reid, F. Berkes, T. Wilbanks, and D. Capistrano, editors. Bridging scales and epistemologies: linking local knowledge and global science in multi-scale assessments. Island Press, Washington, D.C., USA.

Brosius, J. P., A. L. Tsing, and C. Zerner, editors. 2005. Communities and conservation: histories and politics of community-based natural resource management. AltaMira Press, Walnut Creek, California, USA.

Brown, K. 2014. Global environmental change: a social turn for resilience? Progress in Human Geography 38 (1):107-117. http:// dx.doi.org/10.1177/0309132513498837

Carrier, J. G. 1987. Marine tenure and conservation in Papua New Guinea. Pages 142-167 in B. J. McCay and J. M. Acheson, editors. The question of the commons: the culture and ecology of communal resources. University of Arizona Press, Tucson, Arizona, USA. 
Castro, A. P., and E. Nielsen. 2001. Indigenous people and comanagement: implications for conflict management. Environmental Science \& Policy 4(4-5):229-239. http://dx.doi.org/10.1016/ S1462-9011(01)00022-3

Chouin, G. 2002. Sacred groves in history: pathways to the social shaping of forest landscapes in coastal Ghana. IDS Bulletin 33 (1):39-46. http://dx.doi.org/10.1111/j.1759-5436.2002.tb00005.x

Cinner, J., E., and S. Aswani. 2007. Integrating customary management into marine conservation. Biological Conservation 140(3-4):201-216. http://dx.doi.org/10.1016/j.biocon.2007.08.008

Cleaver, F. 2000. Moral ecological rationality, institutions and the management of common property resources. Development and Change 31(2):361-383. http://dx.doi.org/10.1111/1467-7660.00158

Cleaver, F., and T. Frank. 2005. How institutions elude design: river basin management and sustainable livelihoods. BCID Research Paper No. 12. University of Bradford, Bradford, UK.

Cohen, P. J., and S. J. Foale. 2013. Sustaining small-scale fisheries with periodically harvested marine reserves. Marine Policy 37:278-287. http://dx.doi.org/10.1016/j.marpol.2012.05.010

Cote, M., and A. J. Nightingale. 2012. Resilience thinking meets social theory: situating social change in socio-ecological systems (SES) research. Progress in Human Geography 36(4):475-489. http://dx.doi.org/10.1177/0309132511425708

Coulthard, S. 2012. Can we be both resilient and well, and what choices do people have? Incorporating agency into the resilience debate from a fisheries perspective. Ecology and Society 17(1):4. http://dx.doi.org/10.5751/ES-04483-170104

Coulthard, S., D. Johnson, and J. A. McGregor. 2011. Poverty, sustainability and human wellbeing: a social wellbeing approach to the global fisheries crisis. Global Environmental Change 21 (2):453-463. http://dx.doi.org/10.1016/j.gloenvcha.2011.01.003

Crane, T. A. 2010. Of models and meanings: cultural resilience in social-ecological systems. Ecology and Society 15(4):19. [online] URL: http://www.ecologyandsociety.org/vol15/iss4/art19/

Cronon, W. 1995. Uncommon ground: toward reinventing nature. W. W. Norton \& Co., New York, USA.

Cumming, G. S., D. H. M. Cumming, and C. L. Redman. 2006. Scale mismatches in social-ecological systems: causes, consequences, and solutions. Ecology and Society 11(1):14. [online] URL: http://www.ecologyandsociety.org/vol11/iss1/ $\underline{\operatorname{art} 14 /}$

Davidson, D. J. 2010. The applicability of the concept of resilience to social systems: some sources of optimism and nagging doubts. Society \& Natural Resources 23(12):1135-1149. http://dx.doi. org/10.1080/08941921003652940

Davidson-Hunt, I. J., and R. M. O'Flaherty. 2007. Researchers, indigenous peoples, and place-based learning communities. Society \& Natural Resources 20(4):291-305. http://dx.doi. org/10.1080/08941920601161312

Descola, P., and G. Palsson. 1996. Introduction. Pages 1-21 in P. Descola and G. Palsson, editors. Nature and Society. Routledge, London, UK.
Diamond, J. 2005. Collapse: How societies choose to fail or succeed. Viking Press, New York, USA.

Dove, M., and C. Carpenter. 2008. Introduction: major historical currents in environmental anthropology. In M. Dove and C. Carpenter, editors. Environmental anthropology: an historical reader. Blackwell Press, Malden, Massachusetts, USA.

Dressler, W. 2013. Green governmentality and swidden decline on Palawan Island. Transactions of the Institute of British Geographers 39(2):250-264. http://dx.doi.org/10.1111/tran.12026

Drew, J. A. 2005. The use of traditional ecological knowledge in marine conservation. Conservation Biology 19:1286-1293. http:// dx.doi.org/10.1111/j.1523-1739.2005.00158.x

Duit, A., V. Galaz, K. Eckerberg, and J. Ebbesson. 2010. Governance, complexity, and resilience. Global Environmental Change 20:363-368. http://dx.doi.org/10.1016/j.gloenvcha.2010.04.006

Easterly, W. 2014. The tyranny of experts: economists, dictators, and the forgotten rights of the poor. Basic Books, New York, USA.

Eder, J. F. 2005. Coastal resource management and social differences in Philippine fishing communities. Human Ecology 33:147-169. http://dx.doi.org/10.1007/s10745-005-2430-Z

Fabinyi, M. 2009. The political aspects of resilience. Pages 971975 in Proceedings of the 11th International Coral Reef Symposium. Fort Lauderdale, Florida, 7-11 July 2008. Session number 21.

Fabinyi, M., S. Foale, and M. Macintyre. 2014. Managing inequality or managing stocks? An ethnographicperspective on the governance of small-scale fisheries. Fish and Fisheries DOI: 10.1111/faf.12069 http://dx.doi.org/10.1111/faf.12069

Fabinyi, M., M. Knudsen, and S. Segi. 2010. Social complexity, ethnography and coastal resource management in the Philippines. Coastal Management 38:617-632. http://dx.doi.org/10.1080/089$\underline{20753.2010 .523412}$

Ferguson, J. 1994. The anti-politics machine: "development", depoliticization and bureaucratic power in Lesotho. University of Minnesota Press, Minneapolis, Minnesota, USA.

Filer, C. 1990. The Bougainville Rebellion, the mining industry and the process of social disintegration in Papua New Guinea. Canberra Anthropology 13:1-39. http://dx.doi.org/10.1080/0314$\underline{9099009508487}$

Filer, C. 1994. The nature of the human threat to Papua New Guinea's biodiversity endowment. In N. Sekhran and S. Miller, editors. Papua New Guinea biodiversity country study: the costs and benefits of conserving Papua New Guinea's biodiversity. Papua New Guinea Department of Environment and Conservation, Conservation Resource Centre, Port Moresby, Papua New Guinea.

Filer, C. 1997. Compensation, rent and power in Papua New Guinea. Compensation for resource development in Papua New Guinea. National Centre for Development Studies (Pacific Policy Paper 24), Law Reform Commission of PNG (Monograph 6), and Australian National University, Boroko and Canberra.

Filer, C. 2009. A bridge too far: the knowledge problem in the millennium assessment. Pages 84-111 in J. Carrier and P. West, 
editors. Virtualism, governance and practice: vision and execution in environmental conservation. Berghahn Books, New York, USA.

Flyvbjerg, B. 2001. Making social science matter: why social inquiry fails and how it can succeed again. Cambridge University Press, Cambridge, UK. http://dx.doi.org/10.1017/CBO9780511810503

Foale, S., P. Cohen, S. Januchowski, A. Wenger, and M. Macintyre. 2011. Tenure and taboos: origins and implications for fisheries in the Pacific. Fish and Fisheries 12:357-369. http://dx. doi.org/10.1111/j.1467-2979.2010.00395.x

Foale, S., and M. Macintyre. 2000. Dynamic and flexible aspects of property tenure at West Nggela, Solomon Islands: implications for marine resource management. Oceania 71:30-45.

Folke, C. 2006. Resilience: the emergence of a perspective for social-ecological systems analyses. Global Environmental Change 16(3):253-267. http://dx.doi.org/10.1016/j.gloenvcha.2006.04.002

Folke, C., J. Colding, and F. Berkes. 2003. Synthesis: building resilience and adaptive capacity in social-ecological systems. Pages 352-387 in F. Berkes, J. Colding, and C. Folke, editors. Navigating social-ecological systems: building resilience for complexity and change. Cambridge University Press, Cambridge.

Folke, C., T. Hahn, P. Olsson, and J. Norberg. 2005. Adaptive governance of social-ecological systems. Annual Review of Environment and Resources 30:441-473.

Folke, C., L. Pritchard, Jr., F. Berkes, J. Colding, and U. Svedin. 2007. The problem of fit between ecosystems and institutions: ten years later. Ecology and Society 12(1):30. [online] URL: http:// www.ecologyandsociety.org/vol12/iss1/art30/

Forsyth, T. 2003. Critical political ecology: the politics of environmental science. Routledge, London, UK.

Foucault, M. 1972. Archaeology of knowledge. Tavistock, London, UK.

Foucault, M. 1980. Power/knowledge: selected interviews and other writings 1972-1977. Vintage, London, UK.

Frank, A. G. 1975. On Capitalist underdevelopment. Oxford University Press, Bombay, India.

Friedman, J. 1974. Marxism, structuralism and vulgar materialism. Man 9:444-469. http://dx.doi.org/10.2307/2800695

Glaesel, H. 1997. Community approaches to marine management and conservation on the Kenyan coast. Dissertation. University of Wisconsin, Madison, Wisconsin, USA.

Groube, L. M. 1993. Contradictions and malaria in Melanesian and Australian prehistory. Pages 164-186 in M. Spriggs, D. E. Yen, W. Ambrose, R. Jones, A. Thorne, and A. Andrews, editors. A community of culture: the people and prehistory of the Pacific. Australian National University, Canberra, Australia.

Gunderson, L. H., and C. S. Holling. 2002. Panarchy: understanding transformations in human and natural systems. Island Press, Washington D.C., USA.

Harris, M. 1966. The cultural ecology of India's sacred cattle. Current Anthropology 7:51-59. http://dx.doi.org/10.1086/200662
Hatt, K. 2013. Social attractors: a proposal to enhance 'resilience thinking' about the social. Society \& Natural Resources 26(1):3043. http://dx.doi.org/10.1080/08941920.2012.695859

Hirsch, P. D., W. M. Adams, J. P. Brosius, A. Zia, N. Bariola, and J. L. Dammert. 2011. Acknowledging conservation trade-offs and embracing complexity. Conservation Biology 25(2):259-264.

Hornborg, A. 2009. Zero-sum world: challenges in conceptualizing environmental load displacement and ecologically unequal exchange in the world-system. International Journal of Comparative Sociology 50(3-4):237-262. http://dx.doi. org/10.1177/0020715209105141

Johannes, R. E. 1978. Traditional marine conservation methods in Oceania and their demise. Annual Review of Ecology and Systematics 9:349-364. http://dx.doi.org/10.1146/annurev. es.09.110178.002025

Johannes R. E. 2002. The renaissance of community-based marine resource management in Oceania. Annual Reviews of Ecology and Systematics 33:317-340. http://dx.doi.org/10.1146/ annurev.ecolsys.33.010802.150524

Kittinger, J. N. 2013. Human dimensions of small-scale and traditional fisheries in the Asia-Pacific region. Pacific Science 67:315-325. http://dx.doi.org/10.2984/67.3.1

Kremer, A. 1994. Equity in the fishery: a floodplain in N.E. Bangladesh. Research paper R94E. University of Bath, Bath, UK.

Lattas, A. 2011. Logging, violence and pleasure: neoliberalism, civil society and corporate governance in West New Britain. Oceania 81:88-107. http://dx.doi.org/10.1002/j.1834-4461.2011. $\underline{\mathrm{tb} 00095 . \mathrm{x}}$

Leach, E. 1954. Political systems of highland Burma: a study of Kachin social structure. Harvard University Press, Cambridge, Massachusetts, USA.

Leach, M., editor. 2008. Re-framing resilience: a symposium report. STEPS Working Paper 13. STEPS Centre, Brighton, UK.

Lee, R. B., and I. Devore, editors. 1969. Man the hunter. Aldine Publishing Co., Chicago, Illinois, USA.

Li, T. M. 2007. The will to improve: governmentality, development, and the practice of politics. Duke University Press, Durham, North Carolina, USA. http://dx.doi.org/10.1215/9780822389781

Lieber, M. D. 1994. More than a living: fishing and the social order on a Polynesian atoll. Westview Press, Boulder, Colorado, USA.

Macintyre, M. A., and S. J. Foale. 2007. Land and marine tenure, ownership and new forms of entitlement on Lihir: changing notions of property in the context of a gold mining project. Human Organization 66:49-59.

Marshall, N. A., S. E. Park, W. N. Adger, K. Brown, and S. M. Howden. 2012. Transformational capacity and the influence of place and identity. Environmental Research Letters 7(3):034022. http://dx.doi.org/10.1088/1748-9326/7/3/034022

McAnany, P., and N. Yoffee, editors. 2010. Questioning collapse: human resilience, ecological vulnerability, and the aftermath of 
empire. Cambridge University Press, Cambridge, New York, USA.

McShane, T. O., P. D. Hirsch, T. C. Trung, A. N. Songorwa, A. Kinzig, B. Monteferri, D. Mutekanga, H. V. Thang, J. L. Dammert, M. Pulgar-Vidal, M. Welch-Devine, J. P. Brosius, P. Coppolillo, and S. O'Connor. 2011. Hard choices: making tradeoffs between biodiversity conservation and human well-being. Biological Conservation 144:966-972. http://dx.doi.org/10.1016/j. biocon.2010.04.038

Millennium Ecosystem Assessment (MEA). 2003. Ecosystems and human well-being: a framework for assessment. Island Press, Washington, D.C., USA.

Neiland, A. E., S. P. Madakan, and C. Béné. 2005. Traditional management systems, poverty and change in the arid zone fisheries of northern Nigeria. Journal of Agrarian Change 5 (1):117-148. http://dx.doi.org/10.1111/j.1471-0366.2004.00096. $\underline{\mathrm{X}}$

Nelson, D. R., W. N. Adger, and K. Brown. 2007. Adaptation to environmental change: contributions of a resilience framework. Annual Review of Environment and Resources 32:395-419. http:// dx.doi.org/10.1146/annurev.energy.32.051807.090348

Netting, R. Mc. 1990. Links and boundaries: reconsidering the alpine village as ecosystem. Pages 229-246 in E. Moran, editor. The ecosystem approach in anthropology: from concept to practice. University of Michigan, Ann Arbor, Michigan, USA.

O'Brien, K., B. Hayward, and F. Berkes. 2009. Rethinking social contracts: building resilience in a changing climate. Ecology and Society 14(2):12. [online] URL: http://www.ecologyandsociety. org/vol14/iss2/art12/

Olsson, P., and C. Folke. 2001. Local ecological knowledge and institutional dynamics for ecosystem management: a study of Lake Racken watershed, Sweden. Ecosystems 4(2):85-104. http:// dx.doi.org/10.1007/s100210000061

Olsson, P., C. Folke, and T. Hahn. 2004. Social-ecological transformation for ecosystem management: the development of adaptive co-management of a wetland landscape in southern Sweden. Ecology and Society 9(4):2. [online] URL: http://www. ecologyandsociety.org/vo19/iss4/art2/

Orans, M. 1975. Domesticating the functional dragon: an analysis of Piddocke's potlatch. American Anthropologist 77:312-328. http://dx.doi.org/10.1525/aa.1975.77.2.02a00040

Orlove, B. S. 1980. Ecological anthropology. Annual Review of Anthropology 9:235-273. http://dx.doi.org/10.1146/annurev. an.09.100180.001315

Ostrom, E. 1990. Governing the commons: the evolution of institutions for collective action. Cambridge University Press, New York, USA. http://dx.doi.org/10.1017/CBO9780511807763

Ostrom, E. 1998. A behavioral approach to the Rational Choice Theory of collective action. American Political Science Review 92 (1):1-22. http://dx.doi.org/10.2307/2585925

Ostrom, E. 2005. Understanding institutional diversity. Princeton University Press, Princeton, New Jersey, USA.

Ostrom, E. 2007. A diagnostic approach for going beyond panaceas. Proceedings of the National Academy of Sciences of the
United States of America. 104(39):15181-15187. http://dx.doi. org/10.1073/pnas.0702288104

Otto, T. 1997. Baitfish royalties and customary marine tenure in Manus, Papua New Guinea. Anthropological Forum 7:667-690. http://dx.doi.org/10.1080/00664677.1997.9967479

Peet, R., and M. Watts, editors. 2002. Liberation ecologies: environment, development, social movements. Routledge, London, UK.

Pelling, M., and D. Manuel-Navarrete. 2011. From resilience to transformation: the adaptive cycle in two Mexican urban centers. Ecology and Society 16(2):11. [online] URL: http://www. ecologyandsociety.org/vol16/iss2/art11/

Peterson, G. 2000. Political ecology and ecological resilience: an integration of human and ecological dynamics. Ecological Economics 35(3):323-336. http://dx.doi.org/10.1016/S0921-8009 (00)00217-2

Piddocke, S. 1969. The potlatch system of the southern Kwakiutl: a new perspective. In A. P. Vayda, editor. Environment and cultural behaviour. Natural History Press, Garden City, New York, USA.

Plummer, R., and D. R. Armitage. 2007. Charting the new territory of adaptive co-management: a Delphi study. Ecology and Society 12(2):10. [online] URL: http://www.ecologyandsociety. org/vol12/iss $/$ art10/

Rappaport, R. A. 1968. Pigs for the ancestors: ritual ecology of a New Guinea people. Yale University Press, New Haven, Connecticut, USA.

Robards, M. D., M. L. Schoon, C. L. Meek, and N. L. Engle. 2011. The importance of social drivers in the resilient provision of ecosystem services. Global Environmental Change 21:522-529. http://dx.doi.org/10.1016/j.gloenvcha.2010.12.004

Robbins, P. 2004. Political ecology: a critical introduction. Blackwell Publishing, Cornwall, UK.

Sahlins, M. 1978. Culture as protein and profit. New York Review of Books 25(18):45-53.

Scoones, I. 1999. New ecology and the social sciences: what prospects for fruitful engagement? Annual Review of Anthropology 28:479-507. http://dx.doi.org/10.1146/annurev. anthro.28.1.479

Scheffer, M., and F. R. Westley. 2007. The evolutionary basis of rigidity: locks in cells, minds, and society. Ecology and Society 12 (2):36. [online] URL: http://www.ecologyandsociety.org/vol12/ iss $2 / \operatorname{art} 36 /$

Shanin, T., editor. 1971. Peasants and peasant societies. Penguin Modern Sociology Readings. Penguin, Harmondsworth, England.

Shaxon, N. 2011. Treasure islands: tax havens and the men who stole the world. The Bodley Head, London, UK.

Steward, J. 1955. Theory of culture change: the methodology of multilinear evolution. Urbana, University of Illinois Press, Champaign, Illinois, USA.

Strathern, M. 1980. No nature, no culture: the Hagen case. Pages 174-222 in C. C. MacCormack and M. Strathern, editors. Nature, culture and gender. Cambridge University Press, Cambridge, UK. 
Tompkins, E. L., and W. N. Adger. 2004. Does adaptive management of natural resources enhance resilience to climate change? Ecology and Society 9(2):10. [online] URL: http://www. ecologyandsociety.org/vol9/iss2/art10/

Tsing, A. L. 2005. Friction: an ethnography of global connection. Princeton University Press, Princeton, New Jersey, USA.

Vayda, A. P. 1974. Warfare in ecological perspective. Annual Review of Ecology and Systematics 5:183-193. http://dx.doi. org/10.1146/annurev.es.05.110174.001151

Vedeld, T. 2000. Village politics: heterogeneity, leadership and collective action. Journal of Development Studies 36(5):105-134. http://dx.doi.org/10.1080/00220380008422648

Walker, A. 2001. Introduction: simplification and the ambivalence of community. Asia Pacific Journal of Anthropology 2(2):1-20. http://dx.doi.org/10.1080/14442210110001706085

Walker, B., S. Barrett, S. Polasky, V. Galaz, C. Folke, G. Engstrom, F. Ackerman, K. Arrow, S. Carpenter, K. Chopra, G. Daily, P. Ehrlich, T. Hughes, N. Kautsky, S. Levin, K.-G. Mäler, J. Shogren, J. Vincent, T. Xepapadeas, and A. de Zeeuw. 2009. Looming global-scale failures and missing institutions. Science 325 (5946):1345-1346. http://dx.doi.org/10.1126/science.1175325

Walker, B., C. S. Holling, S. R. Carpenter, and A. Kinzig. 2004. Resilience, adaptability and transformability in social-ecological systems. Ecology and Society 9(2):5. [online] URL: http://www. ecologyandsociety.org/vol9/iss2/art5/

Walker, B., L. Gunderson, A. Kinzig, C. Folke, S. Carpenter, and L. Schultz. 2006. A handful of heuristics and some propositions for understanding resilience in social-ecological systems. Ecology and Society 11(1):13. [online] URL: http://www.ecologyandsociety. org/vol11/iss1/art13/

Walker, B. H., and D. A. Salt. 2006. Resilience thinking. Island Press, Washington D.C., USA.

Walker, P. A. 2004. Roots of crisis: historical narratives of tree planting in Malawi. Historical Geography 32:89-109.

Wallerstein, I. 1974. The modern world-system. Vol. I: Capitalist agriculture and the origins of the European world-economy in the sixteenth century. Academic Press, New York, USA.

Westley, F., P. Olsson, C. Folke, T. Homer-Dixon, H. Vredenburg, D. Loorbach, J. Thompson, M. Nilsson, E. Lambin, J. Sendzimi, B. Banerjee, V. Galaz, and S. van der Leeuw. 2011. Tipping toward sustainability: emerging pathways of transformation. Ambio 40 (7):762-780. http://dx.doi.org/10.1007/s13280-011-0186-9

Westley, F., B. Zimmerman, and M. Q. Patton. 2006. Getting to maybe: how the world is changed. Random House, Toronto, Ontario, Canada.

Westley, F. R., O. Tjornbo, L. Schultz, P. Olsson, C. Folke, B. Crona, and Ö. Bodin. 2013. A theory of transformative agency in linked social-ecological systems. Ecology and Society 18(3):27. http://dx.doi.org/10.5751/ES-05072-180327

Wolf, E. 1982. Europe and the people without history. University of California Press, Berkeley, California, USA.
Wollenberg, E., L. Merino, A. Agrawal, and E. Ostrom. 2007. Fourteen years of monitoring community-managed forests: learning from IFRI's experience. International Forestry Review 9 (2):670-684. http://dx.doi.org/10.1505/ifor.9.2.670

Young, O. 2002. The institutional dimensions of environmental change: fit, interplay, and scale. Massachusetts Institute of Technology, Boston, Massachusetts, USA.

Young, O. R. 2010. Institutional dynamics: resilience, vulnerability and adaptation in environmental and resource regimes. Global Environmental Change 20:378-385. http://dx.doi. org/10.1016/j.gloenvcha.2009.10.001

[1] In addition to the social critiques of early ecological anthropology, the heavy emphasis on the "trophic ecology of humans" also neglected other biological factors that impacted profoundly on human populations, most notably diseases such as malaria (Groube 1993). 